\title{
Have artificial lighting and noise pollution caused zoonosis and the COVID-19 pandemic? A review
}

\author{
Shanshan $\mathrm{He}^{1} \cdot$ Wenyuan $\mathrm{Shao}^{2} \cdot \mathrm{Jie} \mathrm{Han}^{3}$ (1) \\ Received: 11 May 2021 / Accepted: 19 July 2021 / Published online: 31 July 2021 \\ (c) The Author(s), under exclusive licence to Springer Nature Switzerland AG 2021
}

\begin{abstract}
Where did the severe acute respiratory syndrome coronavirus 2 (SARS-CoV-2) come from? Did it spread to 'patient zero' through proactive human-animal contact? Why did humans faced an increasing number of zoonotic diseases in the past few decades? In this article, we propose a new theory by which human pollution such as artificial lighting and noise accentuate pathogen shedding from bats and other wild habitants in urban environments. This theory differs from the current hypothesis that wildlife trades and bushmeat consumption largely contribute to the spillover of zoonotic pathogens to humans. As natural reservoirs, bats harbor the greatest number of zoonotic viruses among all mammalian orders, while they also have a unique immune system to maintain functioning. Some bat species roost in proximity with human settlements, including urban communities and surrounding areas that are potentially most impacted by anthropogenic activities. We review the behavioral changes of wild habitants, including bats and other species, caused by environmental pollution such as artificial lighting and noise pollution, with focus on the spillover of zoonotic pathogens to humans. We found that there is a strong positive correlation between environmental stress and the behavior and health conditions of wild species, including bats. Specifically, artificial lighting attracts insectivorous bats to congregate around streetlights, resulting in changes in their diets and improved likelihood of close contact with humans and animals. Moreover, many bat species avoid lit areas by expending more energies on commuting and foraging. Noise pollution has similar effects on bat behavior. Bats exposed to chronic noise pollution have weakened immune functions, increased viral shedding, and declined immunity during pregnancy, lactation, and vulnerable periods due to noised-induced stress. Other wild species exposed to artificial lighting and noise pollution also show stress-induced behaviors and deteriorated health. Overall, evidence supports our hypothesis that artificial lighting and noise pollution have been overlooked as long-term contributors to the spillover of zoonotic pathogens to humans in urban environments.
\end{abstract}

Keywords Coronavirus $\cdot$ SARS-CoV-2 $\cdot$ Artificial lighting $\cdot$ Noise pollution $\cdot$ Bat $\cdot$ Spillover

Jie Han

jiehan@xjtu.edu.cn

1 Department of Environmental Science and Engineering, Xi' an Jiaotong University, Xi' an 710049,

People's Republic of China

2 School of Life Sciences and Technology, Xi' an Jiaotong University, Xi'an 710049, People's Republic of China

3 School of Human Settlements and Civil Engineering, Xi' an Jiaotong University, Xi' an 710049,

People's Republic of China

\section{Introduction}

Anthropocene has been defined by Nobel Prize Laureate Paul J. Crutzen as an era when human activities have started to impact the ecosystem on earth (https://en.wikip edia.org/wiki/Anthropocene). While adverse effects such as pollution and climate change are now well documented, the influence of human activities on zoonosis and the associated epidemics and pandemics is still debated (Ali and Khan 2016; Fawzy et al. 2020; Zheng et al. 2021). Here we discuss some potential links between anthropogenic influences and the behaviors of wildlife, as a possible explanation for the increasingly frequent spillover of zoonotic pathogens to humans. In the past 20 years, zoonotic diseases, such as the severe acute respiratory syndrome (SARS), the Middle East 
respiratory syndrome (MERS) and recently, the novel coronavirus disease (COVID-19), have caused large outbreaks on a regional or global scale (Dai et al. 2021; Khan et al. 2021; Sharma et al. 2020, 2021). Many have speculated that bats, a pervasive species and a major reservoir of coronaviruses and other viral pathogens (Kupferschmidt 2017; Maxmen 2017; Sallard et al. 2021; Segreto et al. 2021), are natural hosts of those novel zoonotic pathogens, including the Severe Acute Respiratory Syndrome Coronavirus 2 (SARSCoV-2) which has caused the recent COVID-19 pandemic with about 160 million people already infected around the globe (WHO 2021). An early comprehensive analysis on mammalian host-virus relationships showed that bats harbor a significantly higher proportion of zoonotic viruses than all other mammalian orders (Olival et al. 2017). There are at least 3200 coronaviruses that infect bats (Burki 2020). As the world is still grappled with the novel coronavirus and its emerging variants (Dai et al. 2021), bats, the pervasive nocturnal species frequently spotted in urban and other human settlements (Fig. 1), are once again under the spotlight (Irving et al. 2021; Watson 2020).

Spillovers of coronaviruses and other zoonotic pathogens to humans have been linked to increased human contacts with pathogen-harboring wildlife species, a reality driven by the continuing expansion and intensification of anthropogenic activities such as agriculture, hunting, and infrastructural developments (Beyer et al. 2021; He et al. 2021). Bats perch in leafage, rock crannies, caves, trees, and constructed structures such as garages, houses, and bridges. They have a wide variety of diets, for instance, insects, nectars, fruits, pollen, fish, and blood (Irving et al. 2021; Kunz et al. 2011). As a group of mobile, social, and virus-harboring wild habitants frequently sighted in human settlements, bats are a unique species warranting systematic studies to understand how climatic and environmental stress factors affect their behavior, health, and virus shedding.
A recent study revealed that global hotspots of climate change drive the increase of richness in bat species distributed in Southeast Asia, while the quantities of coronaviruses present in an area are strongly related with local bat species richness (Beyer et al. 2021). The study suggested that global greenhouse gas emissions may have played a crucial role in the evolution or transmission of zoonotic viruses. Others have found that stable thermal environments and botany areas in urban environments are beneficial for the survival of some bat species, which also become a major factor affecting the biodiversity of bats roosting in those areas (Jung and Threlfall 2016). A widely overlooked aspect, however, is that artificial lighting and noise pollution at night can become major environmental stress factors for wild species in urban communities and other human settlements, including bats. These are important factors to consider given the fact that bats are known to be a pervasive nocturnal species living in cities and city suburbs and have the best hearing of land mammals. In this article, we present the evidence and hypotheses on how artificial lighting and noise pollution affect the behaviors and health of wild habitants, with a focus of our discussions on bats. By linking anthropogenic influences with the occurrence of zoonotic diseases, we found that there is indeed a positive correlation between environmental stress factors and the abnormal behaviors of wild species, including bats, which may have played a significant role in their shedding of viral pathogens and spillover to humans.

\section{The immunity of bats and viral shedding}

Scientists have long been fascinated with the immune systems of bats (Brook and Dobson 2015; Irving et al. 2021; O'Connor 2021). While bats have natural antibody responses to pathogens (Brook and Dobson 2015), intracellular and extracellular infections can have very different effects in bats. For instance, bats infected by viral pathogens
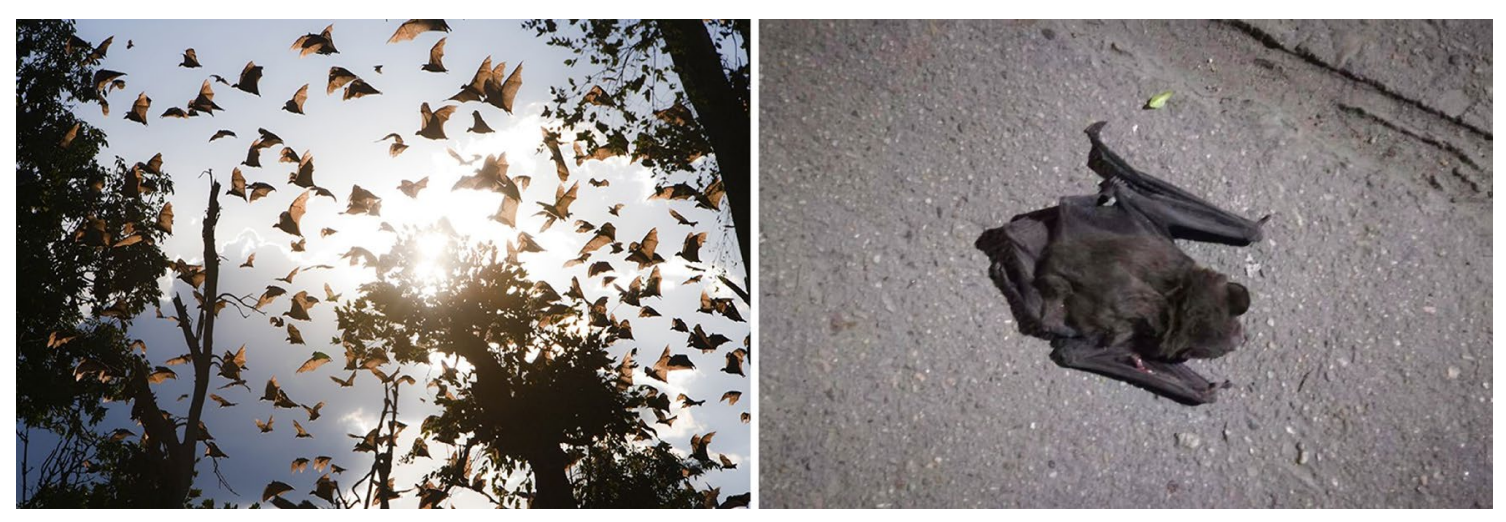

Fig. 1 Bats flying at dusk (left). Photo by Steven Belcher (Minden Pictures). Adopted from Watson (2020). A dead bat sighted on the roadside in the residential community near the university campus of Xi' an Jiaotong University (right). Photo taken by the authors 
generally show no or slight symptoms, but they may experience morbidity to extracellular infections (Afelt et al. 2018; Brook and Dobson 2015). Bats control pathogenesis in microbe-invaded cells by autophagy and apoptosis, which function by avoiding the immunopathological consequences of heightened immune responses in intracellular pathways (Brook and Dobson 2015). Bats are, however, vulnerable to immunopathological responses to extracellular infections. This is exemplified by the widespread white-nose syndrome, a fungal disease caused by Pseudogymnoascus destructans which has killed millions of bats since the early 2000s and resulted in a dramatic decrease of bat populations across North America. Davy et al. (2018) found large quantities of coronavirus RNAs in the intestines of hibernating Little brown bats (Myotis lucifugus) co-infected with the whitenose syndrome, which confirmed that responses of extracellular co-infections had led to amplified coronavirus replication and increased viral shedding from bats.

Two hypotheses have been proposed on the mechanism of virus shedding from bats, namely, the episodic shedding theory and the transient epidemic theory (Plowright et al. 2015). In the first hypothesis, both internal and external stress contribute to the immune response of bats, making it possible for viruses in healthy bats to reproduce themselves and shed off. In the latter, viruses invade bats once again after the immunity of the bat colony declines. As female bats during pregnancy and lactation periods and juvenile bats both have relatively low immunity, they are more likely to be infected by viruses in these periods. By examining fecal droppings, Amman et al. (2012) found that the active infection of Marburg virus remained at 2.7\% (8/301) among 3-month-old bats but increased to $12.4 \%$ (30/241) before they reached six months of age, which coincided with the peak of their birthing season, i.e., twice yearly. Notably, about $80 \%(54 / 65)$ of human infections caused by the Marburg virus occurred during those seasonal pulses of viral shedding events by bats, showing a positive correlation between the infection of Marburg virus in juvenile bats and their spillover to humans. In an earlier study, Drexler et al. (2011) collected pool samples of the greater mouse-eared bat (Myotis myotis) in the attic of a private dwelling in a suburban area over three consecutive years from 2008 to 2010 . The study found strong and specific amplification of RNA viruses occurring upon colony formation and following parturition. The prevalence of coronaviruses in bat feces peaked when roosting started $(77.5 \%)$ in 2008 and about one month after parturition (100\%).

Lower intake of energy and nutrients or abrupt shifts in diets can potentially bolster in-body viral replication and increase viral shedding by bats. Plowright et al. (2008) studied 26 little red flying foxes (Pteropus scapulatus) including both male and female bats that were not pregnant or lactational in fall 2006. They observed overall lower body weights, nutritional stress, deteriorated health, and abnormal diurnal feeding in the bat colony, where $80 \%$ of bats showed 14-42-fold higher seroprevalence of hepatitis E virus than those observed in any other seasons. The study concluded that food shortage and nutrition stress resulted from bad weather were major driving factors of viral shedding from little red flying foxes and the subsequent spread of the virus to horses. In a later study, Plowright et al. (2015) found that Hendravirus-shedding bats had previously experienced low food abundance and nutritional deficiencies. Kessler et al. (2018) found that when their preferred diets were unavailable, the black flying fox (Pteropus alecto) and other pteropodid bats forage on alternative diet sources such as aboriginal and exotic fruits containing low nutrition and energy, toxic metabolites, or showing poor digestibility by bats. Under those circumstances, poor nutritional conditions could become the driving factors for the reactivation of viral infections in bats by a reduction in immunocompetence or immunity trade-offs in pregnant bats (Kessler et al. 2018). Overall, the rate of viral shedding and the number of detectable viruses associated with bat colonies inevitably fluctuate, with periodic increases often linked to nutritional stress, waning maternal immunity, parturition, or inadequate energy consumption.

\section{Artificial lighting}

The use of artificial lighting is a keystone of the modern society, but it also causes ubiquitous light pollution at night. About a quarter of the world's land surfaces between $75^{\circ} \mathrm{N}$ and $60^{\circ} \mathrm{S}$, $88 \%$ of Europe, and almost half of the USA experience lightpolluted nights (Fig. 2). Of those, light pollution in Italy and South Korea was reported as the most severe among G20 countries (Fig. 3) (Falchi et al. 2016). The widespread use of artificial lighting at night in urban communities severely affects the behavior of nocturnal species (Gaston et al. 2015; Stone et al. 2009). A review by Stone et al. (2015) showed that artificial lighting has a tremendous impact on the behaviors and survival of bats, affecting their foraging, commuting, roosting, breeding, and hibernation. Moreover, the spectral range of artificial lighting is generally wider than those of natural light. With the recent developments of light-emitting diodes (LEDs), plenty of outdoor lighting equipment in urban areas switched from conventional long-wavelength light (e.g., highpressure sodium lights) to shorter-wavelength LEDs (Gaston et al. 2015). van Grunsven et al. (2014) found that the majority of moths were attracted to short-wavelength light at night. The fruit fly Drosophila melanogaster, tsetse fly Glossina morsitans, and housefly Musca domestica all preferred ultraviolet light in the 300-380 $\mathrm{nm}$ range (Tokushima et al. 2016). Short-wavelength light emitted from LEDs attract phototaxis insects and thus provide new feeding spots for insectivore bats (Kerbiriou et al. 2020). Indeed, some bat species are known to forage near streetlights and illuminated areas at night. Such 


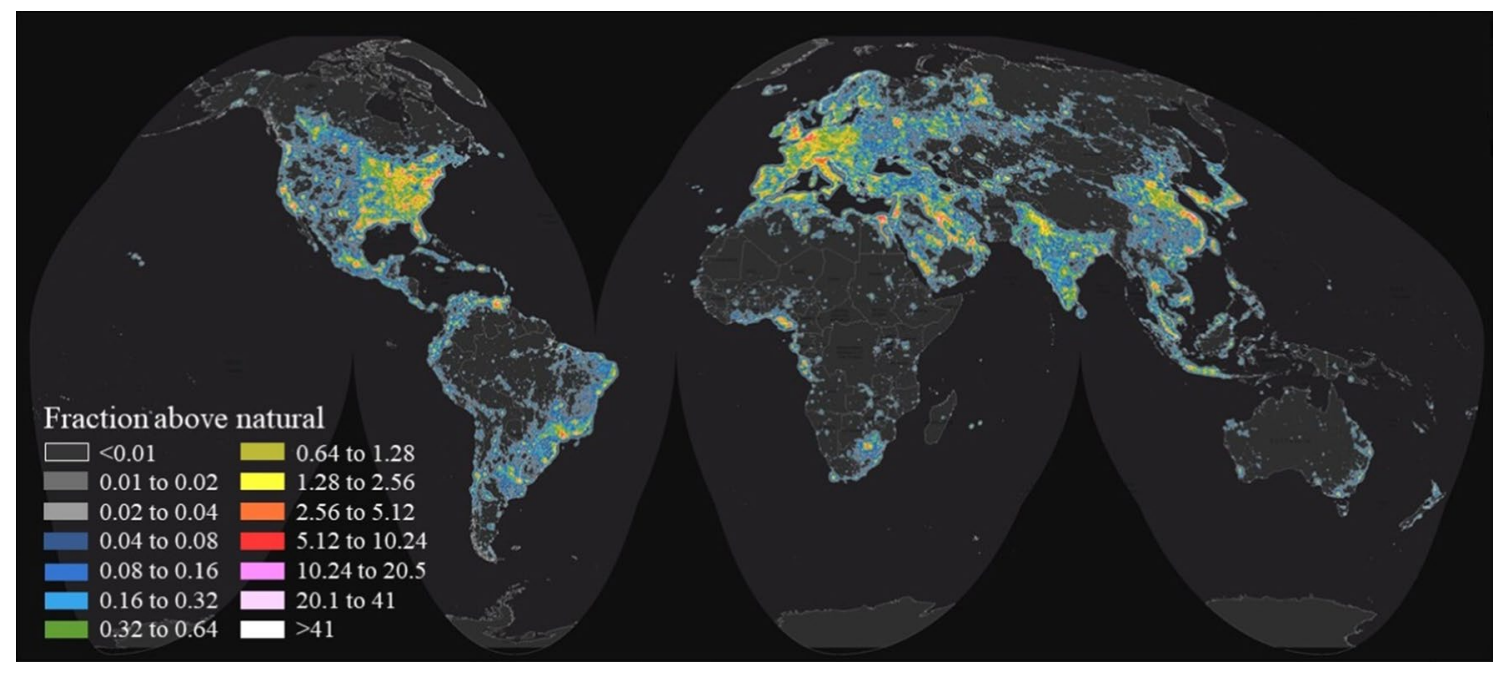

Fig. 2 World map of night sky brightness illuminated by artificial lighting. In two-fold increments, the map shows the artificial sky brightness as a ratio to 'natural sky brightness', which is assumed to be $174 \mu \mathrm{cd} / \mathrm{m}^{2}$. Table insert indicates the numerical range of bright- ness at each designated color level. Reprint from Falchi et al. (2016) with permission from the American Association for the Advancement of Science (AAAS) under a Creative Commons Attribution Noncommercial License 4.0 (CC BY-NC)

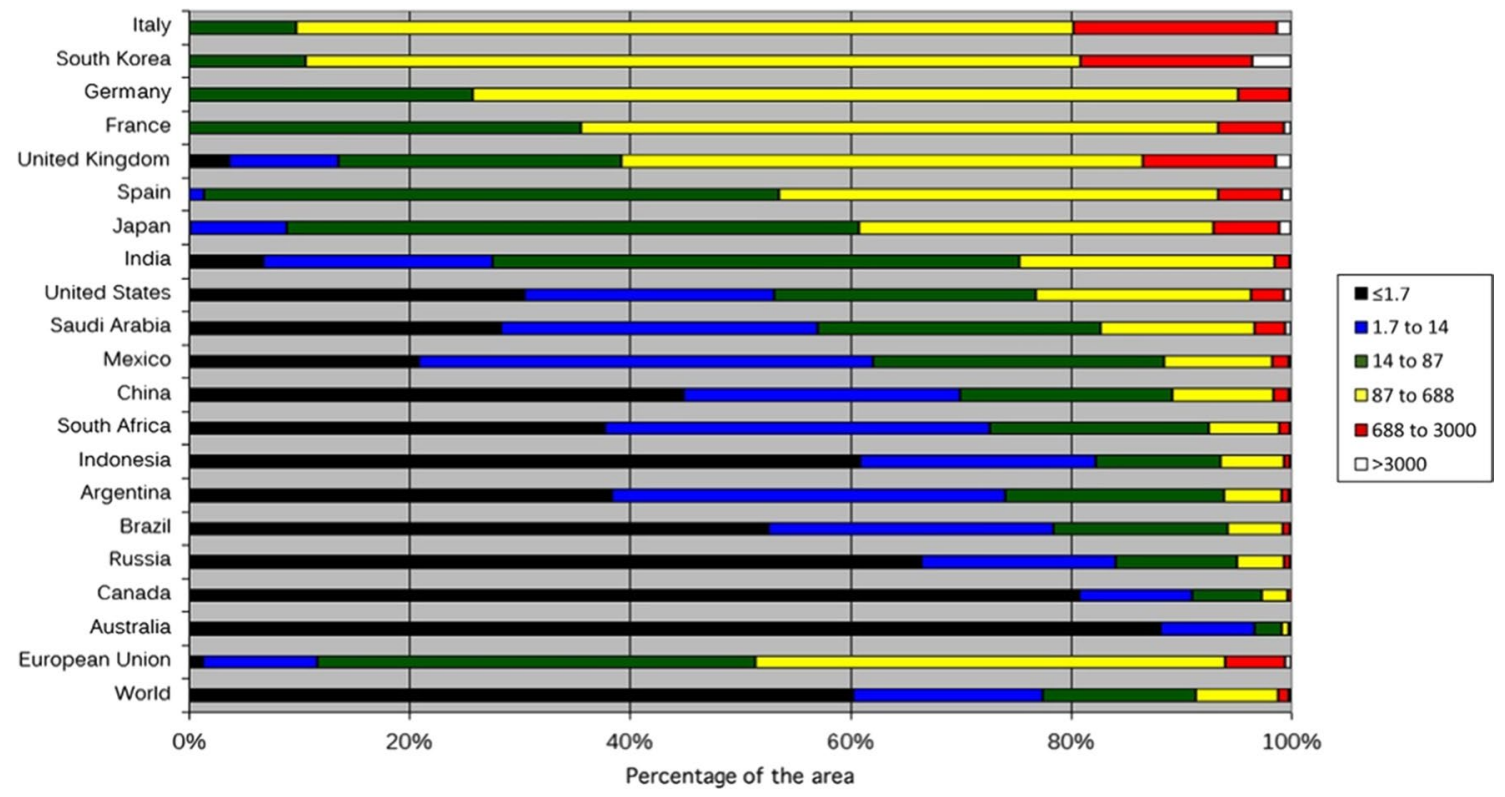

Fig. 3 Light pollution in countries of the G20 group, ranked by the percentage of polluted area based on the three most polluted levels (yellow, red, and white). Color ranges indicate the level of light pollution in $\mu \mathrm{cd} / \mathrm{m}^{2}$. The average percentages of light-polluted areas of

behavior has been confirmed in various bat species including Chalinolobus, Cormura, Cynomops, Diclidurus, Eumops, Epteicus, Lasiurus, Mormopterus, Molossus, Myotis, Nyctalus, Nyctinomops, Pipistrellus, Tadarida, Saccopteryx, and Vespertilio (Stone et al. 2015). An unintended consequence, however, is that bats foraging near artificial lighting sources have altered unnatural diet structures. An earlier study found that in artificially lit areas, bats ingested substantially more the European Union and the world are added as benchmarks. Reprint from Falchi et al. (2016) with permission from the American Association for the Advancement of Science (AAAS) under a Creative Commons Attribution Noncommercial License 4.0 (CC BY-NC)

moths and far less beetles compared with those foraging in naturally dark areas (Cravens et al. 2017).

The ubiquitous use of artificial lighting at night also resulted in the avoidance of lit areas by bats, which interferes with their activities at night. Some bat species avoid artificial lighting and lit areas in their nocturnal predation. Longcore and Rich (2004) reported that while faster-flying bats foraged near streetlights to feed on phototaxis insects, slower-flying bat species 
generally avoided lights. An earlier study found that Eptesicus bottae, a desert-dwelling bat species, merely transited the illuminated area at commuting speeds rather than foraging speeds (Polak et al. 2011). Recently, Cravens and Boyles (2019) found that while it is more likely for red bats (Lasiurus borealis) to forage near lights, the rarer bat species avoided illuminated areas. Other studies also identified reduction of bat activities, especially in areas illuminated by high-intensity LED lights (Kerbiriou et al. 2020). Straka et al. (2020) found that common neutral-white or amber LEDs reduced the activities of all wild cave-roosting species, including Rhinolophus mehelyi, Rhinolophus euryale, Myotis capaccinii, and Miniopterus schreibersii. Among those, the Rhinolophus bats reacted most strongly and refused to fly at all under any artificial lighting treatment in the flight room. Stone et al. (2009) also reported that light pollution may fragment the commuting network by Rhinolophus hipposideros, forcing them to alter their routes. According to the recent observations by Stone et al. (2009), $42 \%$ of bats flew across lights, $30 \%$ turned around before approaching the lights, $26 \%$ flew over or across the hedgerow, and $2 \%$ flew wide or high about the lights. In those cases, artificial lighting may gather light-intolerant bat species into circumscribed dark refugia, thus increasing the competition for depauperate, phototactic insect communities (Cravens and Boyles 2019). Overall, by interfering with the natural behaviors of nocturnal species, light pollution may result in longer flight time, higher stress, lower energy benefits and reduce the success of predation, survival, and reproduction of bats. These environmental stress factors may aggravate viral shedding from bats and facilitate the spillover of bat-harbored zoonotic pathogens to humans.

\section{Noise pollution}

Motorized transportation, land development, resource extraction, and other anthropogenic activities are major sources of noise pollution at night, with effects even seen in the remote wilderness sites (Barber et al. 2010). Using continental-scale models, Buxton et al. (2017) showed that anthropogenic noise levels at least doubled the background noise levels in $63 \%$ of protected areas in the USA, and a tenfold or greater increase in noise levels was seen in $21 \%$ of those areas which exceeded the thresholds known to disturb visitor experience and interfere with the behavior of wildlife species (Fig. 4). In particular, noise-induced reductions in foraging rates and efficiencies have been well documented in bats (Song et al. 2020; Finch et al. 2020). In a recent field study, Finch et al. (2020) showed that traffic noise playback reduced the activity and feeding of five ecologically different species in the Myotis septentrionalis genus, at $20 \mathrm{~m}$ away from the noise source. The mechanism of noise pollution affecting bats is unclear but it may arise from

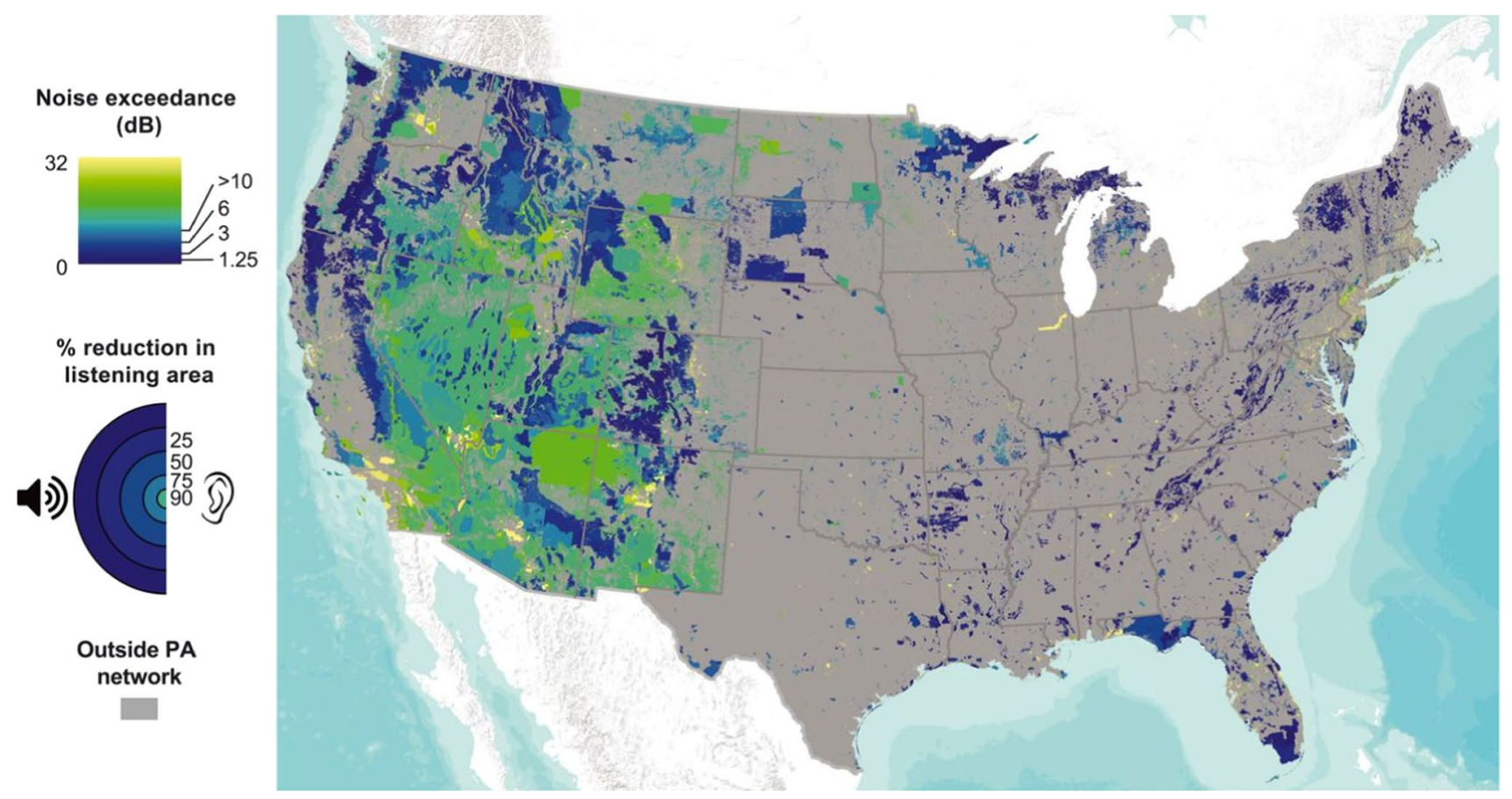

Fig. 4 Median noise exceedance, i.e., the amount that anthropogenic noise increases sound levels above the natural level, in protected areas across the continental USA. Noise exceedance of 1.25, 3.01, 6.02, and $10 \mathrm{~dB}$ corresponds, respectively, to $25,50,75$, and $90 \%$ reductions in listening area, i.e., the area at which an acoustic signal can be detected by humans. Gray areas are outside the protected area network. Reprint from Buxton et al. (2017) with permission from the American Association for the Advancement of Science (AAAS) under a Creative Commons Attribution Noncommercial License 4.0 (CC BY-NC) 
three different aspects. First, noises cause distractions to bats during their foraging and feeding (Geipel et al. 2019). Secondly, some bats actively avoid the aversive stimulus of traffic noise, which reduced their success in foraging (Finch et al. 2020; Luo et al. 2015). Lastly, traffic noise can mask echolocation calls by bats due to their frequency overlaps (Schaub et al. 2008; Siemers and Schaub 2011). Buxton et al. (2020) found that the activity of bats and the number of bat species active were significantly lower at sites near the main road during a motorcycle rally, and the number of bat species active declined to even lower levels 3 weeks after the rally, suggesting that some bats species avoided the main road during the rally and continued to stay away from the previous noise source. The reasons may be that noise disrupted the sleep of nocturnal bats during the day, where lactating females and juveniles were more sensitive to disturbance from traffic noise, and a concurrent shift in the distribution of their insect preys triggered by the traffic noise.

A recent study reported on how chronic noise pollution altered the diet and gene expression of bats. The group of researchers collected 22 non-pregnant adult female Asian particolored bats (Vespertilio sinensis) living under the bridges with heavy traffic flows in the daytime, transferred them to a $12 \mathrm{~m}^{3}$ cage, and kept them in a husbandry room (Song et al. 2020). After being cultivated in a noise-free environment for eight days, noise and silence playbacks were broadcast separately to two bat groups during 08:30-18:30 for 12 consecutive days to test whether short-period traffic noise exposure would change their food intake or have any noticeable health effects on Asian parti-colored bats. The study found that, compared with those kept in the silent environment, bats exposed to traffic noise for 12 days showed a significant increase in their food consumption and energy expenditure. Since traffic noise reduced their foraging efficiency, some bats increased their energy consumption by prolonging their foraging time or foraging in more dangerous habitats and, in other cases, conserved their energy by decreasing activity levels or mating (Song et al. 2020). Chronic noise pollution also has negative impacts on the gene expression alteration of bats, such as metabolic disorder, i.e., causing diabetes and obesity, immune system dysfunction, and elevated risks of cardiovascular and cerebrovascular disease (Song et al. 2020). In conclusion, persisting noise pollution caused by anthropogenic activities disrupts the commuting and foraging behaviors of bats, which can induce stress and affect their activity level and energy expenditure, with significant negative impacts on their health and survival.

\section{Other wild habitants in urban environments}

In recent years, people living in cities and city suburbs have started witnessing cicadas synchronizing their chorus long after sunset, sometimes up to midnight (Cicada Mania 2005; Reddit 2016; TDI 2019). In some areas, bright artificial lighting and persistent high temperatures at night, e.g., due to heat haves or the heat island effects, triggered prolonged singing by cicadas (Fig. 5) (Sheppard et al. 2020). Cicadas are not the only species that exhibit such abnormal behavior. It has been shown that forest-breeding birds near streetlights started singing earlier at dawn than those roosting in the forest (Kempenaers et al. 2010). Also, small rodents, some lagomorphs, marsupials, snakes, fish, aquatic invertebrates, and other taxa forage less at high illumination levels (Longcore and Rich 2004). In a 40-year longitudinal study across Britain from 1968 to 2007 , researchers found that the total abundance of larger moths and
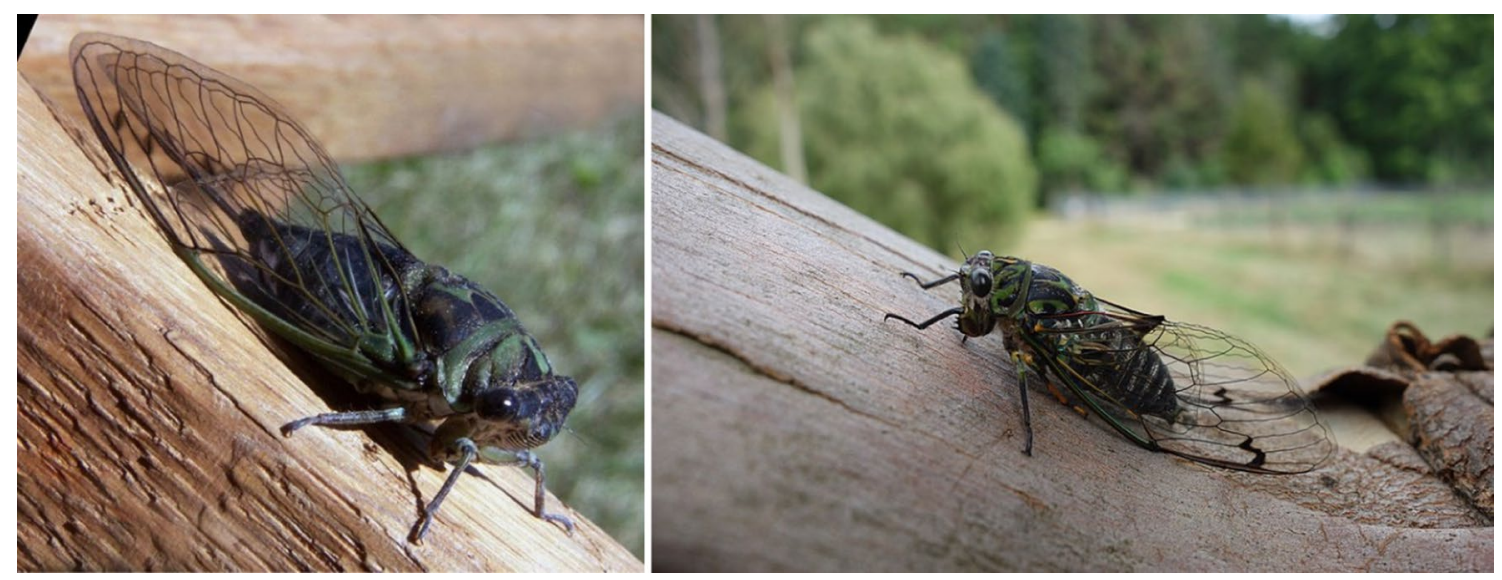

Fig. 5 Linne's cicada (left), a large-bodied annual cicada (Tibicen linnei) native to eastern USA and Canada and a chorus cicada (right) native to New Zealand. Known as 'Nature's thermometer', these treedwelling insects emerge on hot summer days after spending most of their lives underground. By vibrating membranes on their abdomens, male cicadas make loud noises between dawn and dust by synchronizing their chorus to attract mates. Bright artificial lighting and persisting high temperatures at night caused by heatwaves and heat island effects have seen cicadas' singing until late night in some forested areas in urban environments, an abnormal behavior that has only been noted in recent decades. Photos by Bruce Marlin at Cirrusimage.com (left) and Joaquín Salido Bello (right). Reprinted with a Creative Commons Attribution-Share Alike license 
the species of common and widespread larger month declined by $37 \%$ and $67 \%(n=337)$, respectively (Fox et al. 2013). Moth populations also experienced conspicuous decreases in other European countries for several decades, where the increased light pollution is one of the probable driving factors for their long-term population decline (Macgregor et al. 2015). Sanders et al. (2015) pointed out that changes in lighting not only affect the behavior of predators, but preys as well as species immediately related to them, which may have cascading and wide-reaching impact in the ecosystem.

Natural sounds bridge the connection of information networks and adventitious sounds, while masking effects resulted from anthropogenic noises have profound and unpredictable consequence (Barber et al. 2010). Cognitive impairment, stress, distraction, and changed behavior and physiology caused by noise pollution affect both humans and wild habitants in urban environments. Animals use sounds for a variety of reasons, such as to navigate, to search for food, to attract mates, or to avoid predators. Noise pollution makes it difficult for them to accomplish these tasks, which affect their ability to adapt and survive (Santly 2021). One example demonstrating this impact is that the species richness and populations of nocturnal primates, smaller ungulates and carnivores in Africa have undergone significant declines within approximately $30 \mathrm{~m}$ of constructed roads (Laurance et al. 2008). Also, city birds sing higher-frequency songs than their counterparts in rural habitats in order to adapt to traffic noise in urban regions (Nemeth et al. 2015). Chronic exposure to noises can lead to increases in appetite, weight loss, as well as declined immunity in rats, mice, and bats (Song et al. 2020). One study found that exposure to urban noises has an extensive disruptive impact on the sleep composition, architecture, and intensity in Australian magpies (Cracticus tibicen) (Connelly et al. 2020). Further, noise pollution altering the distribution or behavior of pivotal species can have cascading impacts on ecosystem integrity, and further studies are needed to examine these in a holistic manner (Buxton et al. 2017).

The two common environmental stress factors often coexert their influences on species living in urban environments, where nocturnal species with sensitive hearing, such as bats, potentially being most affected (Senzaki et al. 2020). A striking evidence supporting this hypothesis is that researchers found that the strains of coronaviruses isolated from bat fecal matter on their colonies correlated to geographic locations, not the bat species (Lin et al. 2017). With an increasing number of coronaviruses being identified, more closely related coronaviruses from distantly related animals have been observed, suggesting recent interspecies transmission which may eventually lead to their spillover to humans (Woo et al. 2009). The diversity of coronaviruses in bats are most evidenced among all animal hosts, which may be a result of their ability to fly, diversity of species, and their roosting and flocking behavior. Apart from bats, which are unsurprisingly under the spotlight due to the COVID-19 pandemic, primates and rodents also harbor a large variety of zoonotic viruses, compared with other groups of mammals (Olival et al. 2017). In addition, traits such as immunological function, social structure, and other lifehistory variables may trigger some mammalian orders, such as the Chiroptera (bats), Rodentia (rodents), Primates, Cetartiodactyla (even-toed ungulates), and Perissodactyla (odd-toed ungulates), to shed a greater number of viral species (Olival et al. 2017). In short, artificial lighting and anthropogenic noise pollution can affect a wide range of wild species in addition to bats, which may also contribute to the spillover of zoonotic pathogens to humans and animals (Fig. 6).
Fig. 6 Persisting environmental stress factors such as artificial lighting and anthropogenic noise pollution negatively affect the activities, health, and survival of bats and other wild species living in urban environments. Environment-induce stress deteriorates the immune functions and health conditions of these species, resulting in increased viral shedding with risks of spillover of their harbored zoonotic pathogens to humans and animals

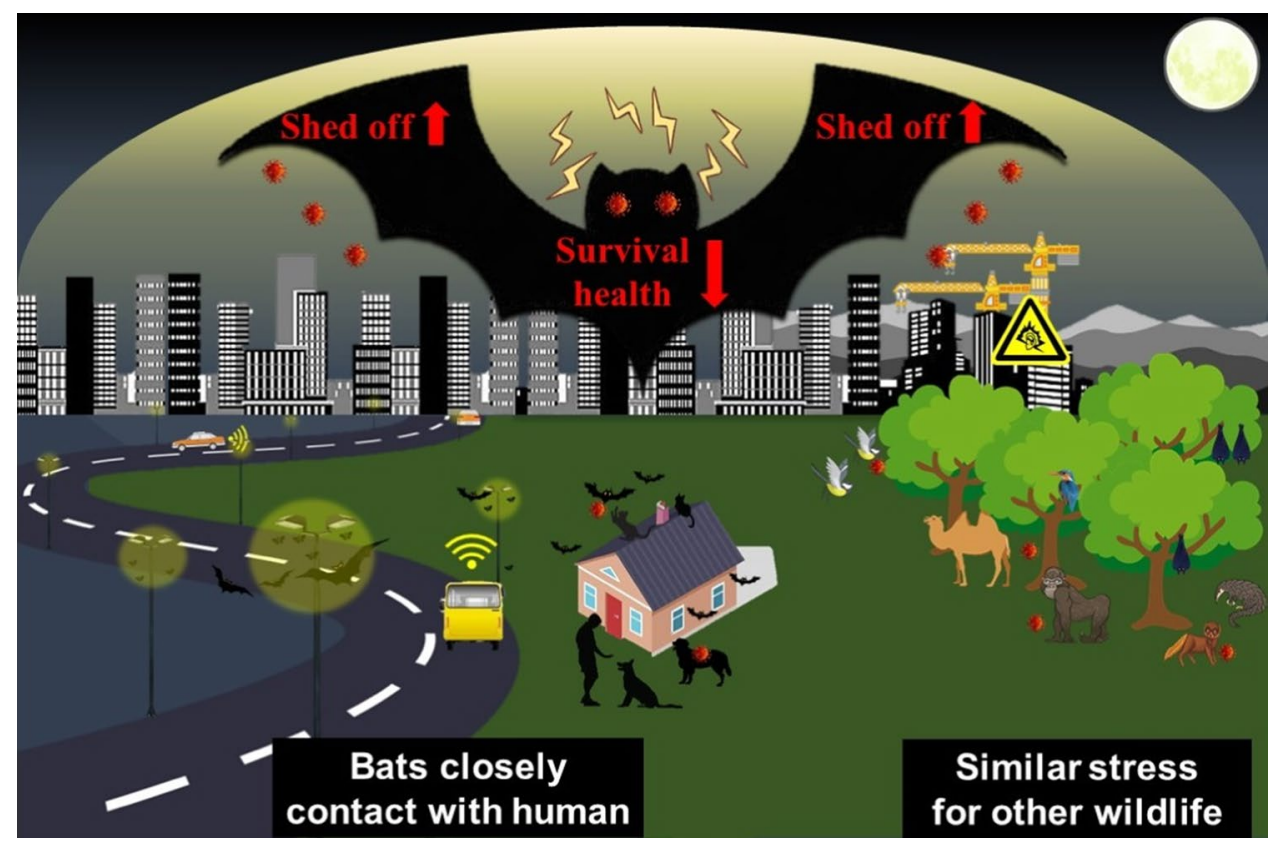




\section{Conclusion}

Aggravating environmental stress factors such as artificial lightening and anthropogenic noise pollution have been widely overlooked as potential long-term driving factors for the shedding and increasingly common spillovers of zoonotic pathogens to humans in recent decades. Particularly, bats host a vast diversity of viral pathogens, including coronaviruses, with a unique immune system allowing themselves to develop little or no symptom after infections. Vulnerability caused by chronic exposure to environmental stress factors such as overwhelming or persisting light and noise pollution, however, can severely affect their activities and health, and dampen their immune functions against pathogenic infections. Specifically, artificial lightening and noise pollution have been shown to alter their diet structure, commuting, foraging, and reproduction behavior, resulting in poor health conditions and increasing viral shedding from bat colonies. Apart from bats, other wild habitants in urban environments are also known to be adversely affected by light and noise pollution. Catalyzed by the COVID-19 pandemic, current legislations seem to solely focus on restricting direct human-animal contacts, while neglecting the persisting environmental stress factors as the chronic and underlying drivers of health deterioration and viral shedding from wild species, which may be the more fundamental cause of zoonotic pathogens spilling over to humans and animals. While wildlife trade can be strictly prohibited and hunting can be better regulated after the current pandemic, humans are still facing the continuous challenge of disrupting the behaviors of wild habitants in urban and surrounding environments and may continue to bear the unpredictable consequences arise from such disruptions. Although in most areas it is unfeasible to reverse the current trend of urbanization and industrialization, we can minimize our footprints and give the quiet and unilluminated nights back to the creatures living in our communities.

Acknowledgements This work was funded by the Young Talent Support Plan of Xi' an Jiaotong University.

\section{Declarations}

Conflict of interest The authors declare that they have no known competing financial interests or personal relationships that could have appeared to influence the work reported in this paper.

\section{References}

Afelt A, Frutos R, Devaux C (2018) Bats, coronaviruses, and deforestation: toward the emergence of novel infectious diseases? Front Microbiol 9:702. https://doi.org/10.3389/fmicb.2018.00702
Ali H, Khan E (2016) Environmental chemistry in the twenty-first century. Environ Chem Lett 15:329-346. https://doi.org/10.1007/ s10311-016-0601-3

Amman BR, Carroll SA, Reed ZD, Sealy TK, Balinandi S, Swanepoel R, Kemp A, Erickson BR, Comer JA, Campbell S, Cannon DL, Khristova ML, Atimnedi P, Paddock CD, Crockett RJK, Flietstra TD, Warfield KL, Unfer R, Katongole-Mbidde E, Downing R, Tappero JW, Zaki SR, Rollin PE, Ksiazek TG, Nichol ST, Towner JS (2012) Seasonal pulses of marburg virus circulation in juvenile rousettus aegyptiacus bats coincide with periods of increased risk of human infection. PLoS Pathog 8(10):e1002877. https://doi.org/10.1371/journal.ppat. 1002877

Barber JR, Crooks K, Fristrup KM (2010) The costs of chronic noise exposure for terrestrial organisms. Trends Ecol Evol 25(3):180 189. https://doi.org/10.1016/j.tree.2009.08.002

Beyer RM, Manica A, Morac C (2021) Shifts in global bat diversity suggest a possible role of climate change in the emergence of SARS-CoV-1 and SARS-CoV-2. Sci Total Environ 767:145413. https://doi.org/10.1016/j.scitotenv.2021.145413

Brook CE, Dobson AP (2015) Bats as 'special' reservoirs for emerging zoonotic pathogens. Trends Microbiol 23(3):172-180. https://doi. org/10.1016/j.tim.2014.12.004

Burki T (2020) The origin of SARS-CoV-2. Lancet Infect Dis 20(9):1018-1019. https://doi.org/10.1016/S1473-3099(20) 30641-1

Buxton RT, McKenna MF, Brown E, Ohms R, Hammesfahr A, Angeloni LM, Crooks KR, Wittemyer G (2020) Varying behavioral responses of wildlife to motorcycle traffic. Glob Ecol Conserv 21:e00844. https://doi.org/10.1016/j.gecco.2019.e00844

Buxton RT, McKenna MF, Mennitt D, Fristrup K, Crooks K, Angeloni L, Wittemyer G (2017) Noise pollution is pervasive in U.S. protected areas. Science 356(6337):531-533. https://doi.org/10.1126/ science.aah4783

Connelly F, Johnsson RD, Aulsebrook AE, Mulder RA, Hall ML, Vyssotski AL, Lesku JA (2020) Urban noise restricts, fragments, and lightens sleep in Australian magpies. Environ Pollut 267:115484. https://doi.org/10.1016/j.envpol.2020.115484

Cravens ZM, Boyles JG (2019) Illuminating the physiological implications of artificial light on an insectivorous bat community. Oecologia 189:69-77. https://doi.org/10.1007/s00442-018-4300-6

Cravens ZM, Brown VA, Divoll TJ, Boyles JG (2017) Illuminating prey selection in an insectivorous bat community exposed to artificial light at night. J Appl Ecol 55(2):705-713. https://doi.org/10.1111/ 1365-2664.13036

Dai H, Han J, Lichtfouse E (2021) Smarter cures to combat COVID-19 and future pathogens: a review. Environ Chem Lett 19:2759-2771. https://doi.org/10.1007/s10311-021-01224-9

Davy CM, Donaldson ME, Subudhi S, Rapin N, Warnecke L, Turner JM, Bollinger TK, Kyle CJ, Dorville NASY, Kunkel EL, Norquay KJO, Dzal YA, Willis CKR, Misra V (2018) White-nose syndrome is associated with increased replication of a naturally persisting coronaviruses in bats. Sci Rep 8:15508. https://doi.org/10. 1038/s41598-018-33975-x

Drexler JF, Corman VM, Wegner T, Tateno AF, Zerbinati RM, GlozaRausch F, Seebens A, Müller MA, Drosten C (2011) Amplification of emerging viruses in a bat colony. Emerg Infect Dis 17(3):449-456. https://doi.org/10.3201/eid1703.100526

Falchi F, Cinzano P, Duriscoe D, Kyba CCM, Elvidge CD, Baugh K, Portnov BA, Rybnikova NA, Furgoni R (2016) The new world atlas of artificial night sky brightness. Sci Adv 2(6):e1600377. https://doi.org/10.1126/sciadv.1600377

Fawzy S, Osman AI, Doran J, Rooney DW (2020) Strategies for mitigation of climate change: a review. Environ Chem Lett 18:20692094. https://doi.org/10.1007/s10311-020-01059-w 
Finch D, Schofield H, Mathews F (2020) Traffic noise playback reduces the activity and feeding behaviour of free-living bats. Environ Pollut 263:114405. https://doi.org/10.1016/j.envpol.2020.114405

Fox R, Parsons MS, Chapman JW, Woiwod IP, Warren MS, Brooks DR (2013) The State of Britain's Larger Moths. Butterfly Conservation \& Rothamsted Research, Wareham, Dorset, UK. https://butte rfly-conservation.org/sites/default/files/1state-of-britains-largermoths-2013-report.pdf. Assessed on 14 May 2021

Gaston KJ, Visser ME, Hölker F (2015) The biological impacts of artificial light at night: the research challenge. Philos Trans R Soc B Biol Sci 370:20140133. https://doi.org/10.1098/rstb.2014.0133

Geipel I, Amin B, Page RA, Halfwerk W (2019) Does bat response to traffic noise support the misleading cue hypothesis? Behav Ecol 30(6):1775-1781. https://doi.org/10.1093/beheco/arz148

He S, Han J, Lichtfouse E (2021) Backward transmission of COVID-19 from humans to animals may propagate reinfections and induce vaccine failure. Environ Chem Lett 19:763-768. https://doi.org/ 10.1007/s10311-020-01140-4

Irving AT, Ahn M, Goh G, Anderson DE, Wang L (2021) Lessons from the host defences of bats, a unique viral reservoir. Nature 589:363-370. https://doi.org/10.1038/s41586-020-03128-0

Jung K, Threlfall CG (2016) Urbanisation and its effects on bats: a global meta-analysis. In: Voigt C, Kingston T (eds) Bats in the anthropocene: conservation of bats in a changing world. Springer, Cham

Kempenaers B, Borgström P, Loës P, Schlicht E, Valcu M (2010) Artificial night lighting affects dawn song, extra-pair siring success, and lay date in songbirds. Curr Biol 20(19):1735-1739. https:// doi.org/10.1016/j.cub.2010.08.028

Kerbiriou C, Barré K, Mariton L, Pauwels J, Zissis G, Robert A, Le Viol I (2020) Switching LPS to LED streetlight may dramatically reduce activity and foraging of bats. Diversity 12(4):165. https:// doi.org/10.3390/d12040165

Kessler MK, Becker DJ, Peel AJ, Justice NV, Lunn T, Crowley DE, Jones DN, Eby P, Sánchez CA, Plowright RK (2018) Changing resource landscapes and spillover of henipaviruses. Ann New York Acad Sci 1429(1):78-99. https://doi.org/10.1111/nyas.13910

Khan AH, Tirth V, Fawzy M, Mahmoud AED, Khan NA, Ahmed S, Ali SS, Akram M, Hameed L, Islam S, Das G, Roy S, Dehghani MH (2021) COVID-19 transmission, vulnerability, persistence and nanotherapy: a review. Environ Chem Lett 19:2773-2787. https://doi.org/10.1007/s10311-021-01229-4

Kunz TH, de Torrez EB, Bauer D, Lobova T, Fleming TH (2011) Ecosystem services provided by bats. Ann N Y Acad Sci 1223(1):138. https://doi.org/10.1111/j.1749-6632.2011.06004.x

Kupferschmidt K (2017) Bats really do harbor more dangerous viruses than other species. Science. https://doi.org/10.1126/science.aan70 01

Laurance WF, Croes BM, Guissouegou N, Buji R, Dethier M, Alonso A (2008) Impacts of roads, hunting, and habitat alteration on nocturnal mammals in african rainforests. Conserv Biol 22(3):721732. https://doi.org/10.1111/j.1523-1739.2008.00917.x

Lin XD, Wang W, Hao ZY, Wang ZX, Guo WP, Guan XQ, Wang MR, Wang HW, Zhou RH, Li MH, Tang GP, Wu J, Holmes EC, Zhang YZ (2017) Extensive diversity of coronavirus in bats from China. Virology 507:1-10. https://doi.org/10.1016/j.virol.2017.03.019

Longcore T, Rich C (2004) Ecological light pollution. Front Ecol Environ 2(4):191-198. https://doi.org/10.1890/1540-9295(2004) 002[0191:ELP]2.0.CO;2

Luo J, Siemers BM, Koselj K (2015) How anthropogenic noise affects foraging. Glob Change Biol 21(9):3278-3289. https://doi.org/10. $1111 / \mathrm{gcb} .12997$

Macgregor CJ, Pocock MJO, Fox R, Evans DM (2015) Pollination by nocturnal Lepidoptera, and the effects of light pollution: a review. Ecol Entomol 40(3):187-198. https://doi.org/10.1111/een.12174
Cicada Mania (2005) Do cicadas sing at night? https://www.cicadamania.com/cicadas/do-cicadas-sing-at-night/. Accessed 14 May 2021

Maxmen A (2017) Bats are global reservoir for deadly coronaviruses. Nature 546:340. https://doi.org/10.1038/nature.2017.22137

Nemeth E, Pieretti N, Zollinger SA, Geberzahn N, Partecke J, Miranda AC, Brumm H (2015) Bird song and anthropogenic noise: vocal constraints may explain why birds sing higher-frequency songs in cities. Proc R Soc B Biol Sci 280(1754):20122798. https://doi. org/10.1098/rspb.2012.2798

O'Connor KC (2021) Bats are "blind" to the deadly effects of viruses. Sci Immunol 3(24):eaau559. https://doi.org/10.1126/sciimmunol. aau2259

Olival KJ, Hosseini PR, Zambrana-Torrelio C, Ross N, Bogich TL, Daszak P (2017) Host and viral traits predict zoonotic spillover from mammals. Nature 546(7660):646-650. https://doi.org/10. 1038/nature22975

Plowright RK, Field HE, Smith C, Divljan A, Palmer C, Tabor G, Daszak P, Foley JE (2008) Reproduction and nutritional stress are risk factors for Hendra virus infection in little red flying foxes (Pteropus scapulatus). Proc R Soc B Biol Sci 275(1636):861-869. https://doi.org/10.1098/rspb.2007.1260

Plowright RK, Eby P, Hudson PJ, Smith IL, Westcott D, Bryden WL, Middleton D, Reid PA, McFarlane RA, Martin G, Tabor GM, Skerratt LF, Anderson DL, Crameri G, Quammen D, Jordan D, Freeman P, Wang LF, Epstein JH, Marsh GA, Kung NY, McCallum $\mathrm{H}$ (2015) Ecological dynamics of emerging bat virus spillover. Proc R Soc B Biol Sci 282(1798):20142124. https://doi.org/ 10.1098/rspb.2014.2124

Polak T, Korine C, Yair S, Holderied MW (2011) Differential effects of artificial lighting on flight and foraging behaviour of two sympatric bat species in a desert. J Zool 285(1):21-27. https://doi.org/ 10.1111/j.1469-7998.2011.00808.x

Reddit (2016) Anyone else unnerved by the cicadas screaming late into the night? https://www.reddit.com/r/chicago/comments/51j4dc/ anyone_else_unnerved_by_the_cicadas_screaming/. Accessed on 14 May 2021

Sallard E, Halloy J, Casane D, Decroly E, van Helden J (2021) Tracing the origins of SARS-COV-2 in coronavirus phylogenies: a review. Environ Chem Lett 19:769-785. https://doi.org/10.1007/ s10311-020-01151-1

Sanders D, Kehoe R, Tiley K, Bennie J, Cruse D, Davies TW, van Veen FJF, Gaston KJ (2015) Artificial nighttime light changes aphid-parasitoid population dynamics. Sci Rep 5:15232. https:// doi.org/10.1038/srep15232

Santly M (2021) Noise pollution. https://www.nationalgeographic.org/ encyclopedia/noise-pollution/. Accessed on 14 May 2021

Schaub A, Ostwald J, Siemers BM (2008) Foraging bats avoid noise. J Exp Biol 211(19):3174-3180. https://doi.org/10.1242/jeb.022863

Segreto R, Deigin Y, McCairn K, Sousa A, Sirotkin D, Sirotkin K, Couey JJ, Jones A, Zhang D (2021) Should we discount the laboratory origin of COVID-19? Environ Chem Lett 19:2743-2757. https://doi.org/10.1007/s10311-021-01211-0

Senzaki M, Barber JR, Phillips JN, Carter NH, Cooper CB, Ditmer MA, Fristrup KM, McClure CJW, Mennitt DJ, Tyrrell LP, Vukomanovic J, Wilson AA, Francis CD (2020) Sensory pollutants alter bird phenology and fitness across a continent. Nature 587:605-609. https://doi.org/10.1038/s41586-020-2903-7

Sharma VK, Jinadatha C, Lichtfouse E (2020) Environmental chemistry is most relevant to study coronavirus pandemics. Environ Chem Lett 18:993-996. https://doi.org/10.1007/s10311-020-01017-6

Sharma VK, Jinadatha C, Lichtfouse E, Decroly E, van Helden J, Choi H, Chatterjee P (2021) COVID-19 epidemiologic surveillance using wastewater. Environ Chem Lett 19:1911-1915. https://doi. org/10.1007/s10311-021-01188-w 
Sheppard LW, Mechtley B, Walter JA, Reuman DC (2020) Self-organizing cicada choruses respond to the local sound and light environment. Ecol Evol 10(10):4471-4482. https://doi.org/10.1002/ ece 3.6213

Siemers BM, Schaub A (2011) Hunting at the highway: traffic noise reduces foraging efficiency in acoustic predators. Proc R Soc B Biol Sci 278(1712):1646-1652. https://doi.org/10.1098/rspb. 2010.2262

Song SJ, Chang Y, Wang DP, Jiang TL, Feng J, Lin AQ (2020) Chronic traffic noise increases food intake and alters gene expression associated with metabolism and disease in bats. J Appl Ecol 57(10):1915-1925. https://doi.org/10.1111/1365-2664.13710

Stone EL, Jones G, Harris S (2009) Street lighting disturbs commuting bats. Curr Biol 19(13):1123-1127. https://doi.org/10.1016/j. cub.2009.05.058

Stone EL, Harris S, Jones G (2015) Impacts of artificial lighting on bats: a review of challenges and solutions. Mamm Biol 80(3):213219. https://doi.org/10.1016/j.mambio.2015.02.004

Straka TM, Greif S, Schultz S, Goerlitz HR, Voigt CC (2020) The effect of cave illumination on bats. Glob Ecol Conserv 21:e00808. https://doi.org/10.1016/j.gecco.2019.e00808

TDI (The Dong-A Ilbo) (2019) Cicada noises make people hard to sleep at night. https://www.donga.com/en/article/all/20190806/ 1809817/1/Cicada-noises-make-people-hard-to-sleep-at-night. Accessed on 14 May 2021

Tokushima Y, Uehara T, Yamaguchi T, Arikawa K, Kainoh Y, Shimada M (2016) Broadband photoreceptors are involved in violet light preference in the parasitoid fly Exorista japonica. PLoS ONE 11(8):e0160441. https://doi.org/10.1371/journal.pone.0160441 van Grunsven RHA, Donners M, Boekee K, Tichelaar I, van Geffen KG, Groenendijk D, Berendse F, Veenendaal EM (2014) Spectral composition of light sources and insect phototaxis, with an evaluation of existing spectral response models. J Insect Conserv 18:225-231. https://doi.org/10.1007/s10841-014-9633-9

Watson C (2020) Bats are a key source of human viruses: but they're not special. Nature. https://doi.org/10.1038/ d41586-020-01096-z

WHO (World Health Organization) (2021) WHO Coronavirus (COVID-19) Dashboard. https://covid19.who.int/. Accessed on 14 May 2021

Woo PCY, Lau SKP, Huang Y, Yuen K (2009) Coronavirus diversity, phylogeny and interspecies jumping. Exp Biol Med 234(10):1117-1127. https://doi.org/10.3181/0903-MR-94

Zheng S, Fu Y, Sun Y, Zhang C, Wang Y, Lichtfouse E (2021) High resolution mapping of nighttime light and air pollutants during the COVID-19 lockdown in Wuhan. Environ Chem Lett 19:34773485. https://doi.org/10.1007/s10311-021-01222-x

Zhong NS, Zheng BJ, Li YM, Poon LLM, Xie ZH, Chan KH, Li PH, Tan SY, Chang Q, Xie JP, Liu XQ, Xu J, Li DX, Yuen KY, Peiris JSM, Guan Y (2003) Epidemiology and cause of severe acute respiratory syndrome (SARS) in Guangdong, People's Republic of China, in February. Lancet 362(9393):1353-1358. https://doi. org/10.1016/S0140-6736(03)14630-2

Publisher's Note Springer Nature remains neutral with regard to jurisdictional claims in published maps and institutional affiliations. 